\title{
Characteristics of storm surges in German estuaries
}

\author{
Andreas Plüß*, Elisabeth Rudolph, Dirk Schrödter \\ The Federal Waterways Engineering and Research Institute, Coastal Division (BAW-AK), Wedeler Landstrasse 157, \\ 22559 Hamburg, Germany
}

\begin{abstract}
Storms over the North Sea can cause storm surges in the the German Bight that reach into the Ems, Jade-Weser and Elbe estuaries. The effect in each estuary can vary due to the different hydrographical structure, bathymetry, location in the the German Bight, exposure to wind direction and fresh-water discharge. A coupled meteorological and hydrodynamical numerical model was used to investigate the relative importance of these effects. With this model the impact of variations in wind speed and direction, in topography, or in fresh-water discharge can be investigated separately or in combination for historical or artificial storm surges. A better insight into the storm surge 'sensitivity' of the individual estuaries is obtained.
\end{abstract}

KEY WORDS: Storm surge $\cdot$ Estuaries $\cdot$ Hydrodynamic $\cdot$ Wind $\cdot$ Analysis $\cdot$ Sensivity Resale or republication not permitted without written consent of the publisher

\section{MOTIVATION}

Storms over the North Sea cause storm surges in the estuaries along the German coast. The progress and height of the actual storm surge in each estuary depends on the meteorological situation, the phase and height of the tide, and the surge within the inner German Bight (see Fig. 1). Furthermore, the hydrographical structure, the location, alignment and shape of the estuary mouth, the fresh-water discharge before and during the storm surge, and the regional and local wind field over each estuary are of major importance.

Fig. 1 shows the model areas for the main estuaries opening into the German Bight. It gives an impression of the different lengths, widths, shapes and orientation of the estuaries.

The model results for the Elbe and Ems estuaries are documented in detail in the following sections.

*E-mail: pluess@hamburg.baw.de

\section{MODEL DESCRIPTION}

To investigate meteorological and hydrodynamic processes in the German Bight and especially in the Ems, Jade-Weser and Elbe estuaries, a one-waycoupled meteorological and hydrodynamic model was
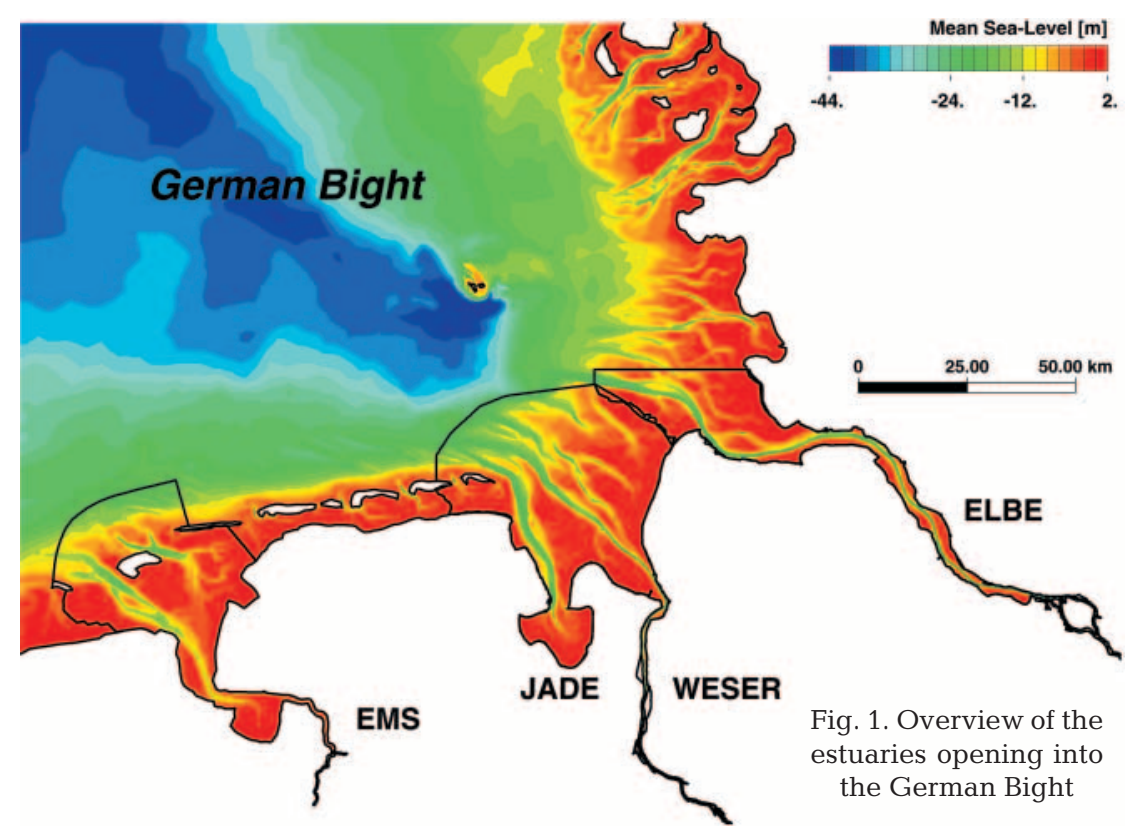

Fig. 1. Overview of the estuaries opening into the German Bight 
developed. The model describes the entire area which can be inundated by storm surge water masses. Wetting and drying of intertidal flats and flood plains are included in the models.

To run a sophisticated storm surge model, it is necessary to have reliable and detailed information about the local and regional wind field which is influenced, especially in coastal areas, by the different roughnesses of the individual land and water surfaces. In order to calculate the correct time dependent wind field in tidal areas, it is also necessary to take the process of wetting and drying of the intertidal flats into account. A potential flow model (mass consistent wind, MCW) was applied to generate consistent wellresolved wind fields in a sufficient quadrilateral resolution (Ems: $250 \mathrm{~m}$, Elbe: $400 \mathrm{~m}$ ) every $2 \mathrm{~h}$ during the total storm surge period and for the entire domain of each estuary. The MCW meteorological numerical model was provided through a cooperation with the DWD (Deutscher Wetterdienst) (Schmidt \& Pätsch 1992).

To analyse and characterize the wind fields of each storm surge, a special software was developed showing, for example, the:

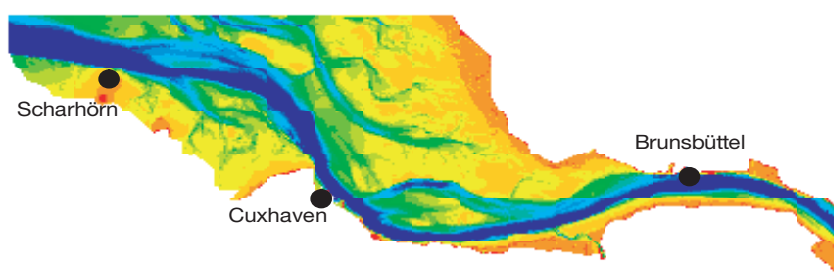

Fig. 2. Model bathymetry of the Elbe estuary

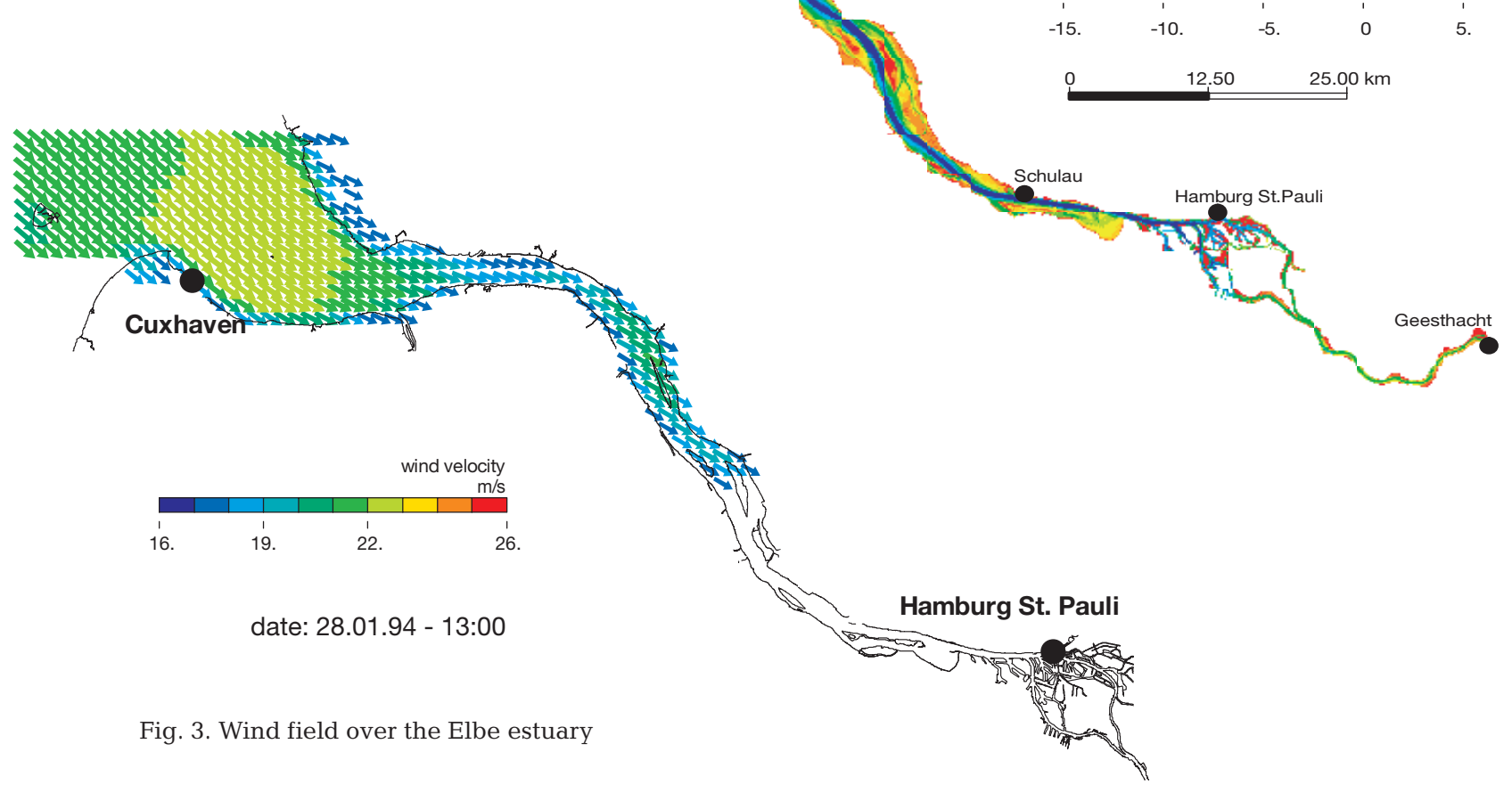

- distribution of maximum/minimum wind velocities

- distribution of the duration of maximum/minimum wind velocities

- maximum/minimum wind velocities for direction sectors

- frequency distribution of wind velocities.

Using this calculated data, the model was run several times for each estuary. The results of the water level elevations were compared with measurements at several tide gauges. For the verification and validation of the models, it is important to reproduce not only the top surge water level (TSWL) but also the complete can obtain information about the change of the current velocities due to storm surges using different scenarios. The current velocities, for example, can be used to investigate the energy balance of storm surges while taking into account wind and bottom drag. To evaluate storm surge sensitivity, different model runs were done by varying the fresh-water discharge, the bathymetry in combination with man-made structures and the wind intensity and direction. Two significant storm surges with different characteristics were investigated: January 28, 1994 (high fresh-water discharge, broad surge); and January 3, 1976 (medium discharge, steep surge). In this paper we will concentrate on the storm surge of January 28, 1994. storm surge dynamics in each estuary. In this way one 
Fig. 4. Duration of maximum wind field over the Elbe estuary

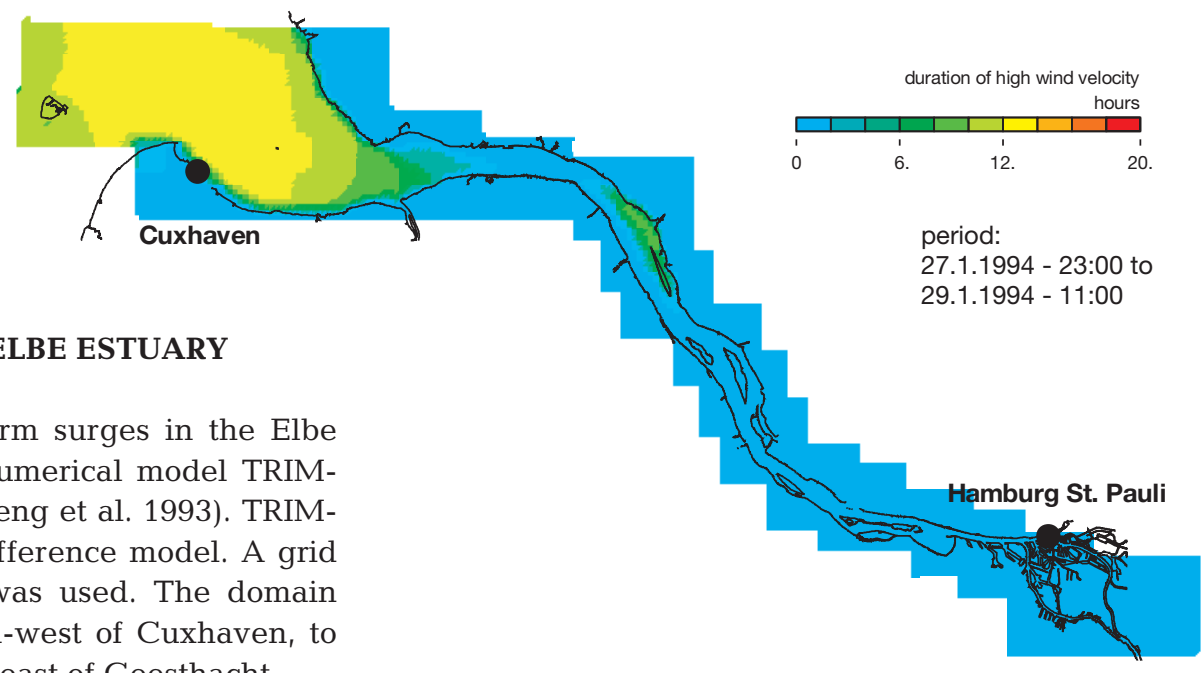

sured at Scharhörn during this period seems to be characteristic for the mouth of the Elbe estuary. As the influence of the rougher land becomes more important upstream of Brunsbüttel, the relatively high wind measured at Scharhörn results in an overestimation of

13:00 $\mathrm{h}$ local time. Wind velocity vectors greater than $18 \mathrm{~m} \mathrm{~s}^{-1}$ extend far upstream of the mouth of the estuary. (Note that velocities lower than $16 \mathrm{~m} \mathrm{~s}^{-1}$ are not shown.) The decrease in the duration of high wind velocities upstream can be seen in Fig. 4.

The hydrodynamics of the storm surge of January 28, 1994 was modelled using measurements of wind, tide and fresh-water discharge as boundary values. A good agreement between simulated (blue) and measured water level was obtained (Fig. 5). Fig. 5 also shows the influence of the regional and local wind (blue) in comparison with the no wind situation (green).

The effect of the fresh-water discharge and the regional/local wind field over the estuary on the storm surge level of January 28, 1994 was investigated. Wind and discharge were modified in order to find areas which were influenced by these variations.

The development of the TSWL along the Elbe estuary from the mouth to Geesthacht for the wind input sensitivity study is shown in Fig. 6. Within a distance of $10 \mathrm{~km}$ from the seaward boundary, all 3 water levels are nearly the same. Here, the calculated water levels are primarily influenced by the boundary values (measured water levels). But, in the area of Cuxhaven, the use of no additional wind input already leads to an underestimation of the water level during the storm surge. The other 2 scenarios show the same water level up to Brunsbüttel. This indicates that the wind mea-

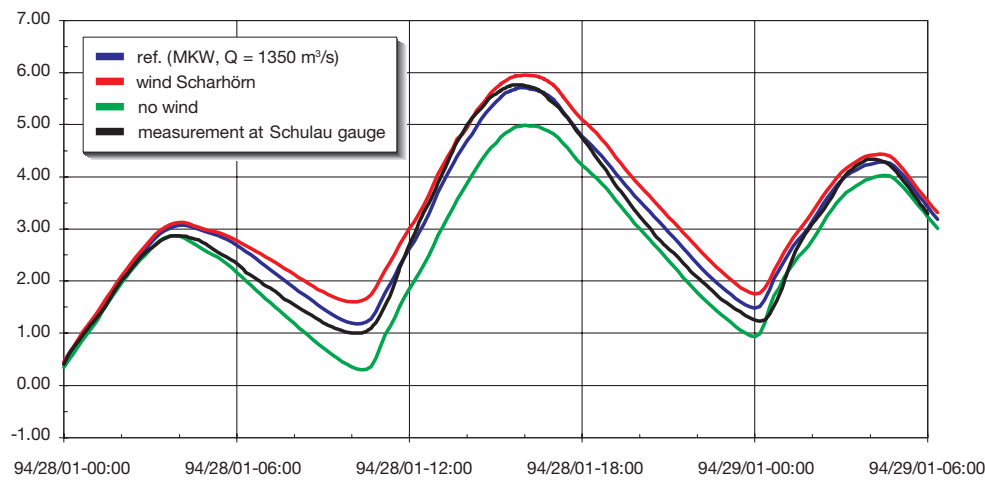

Fig. 5. Measured and calculated water levels at Schulau

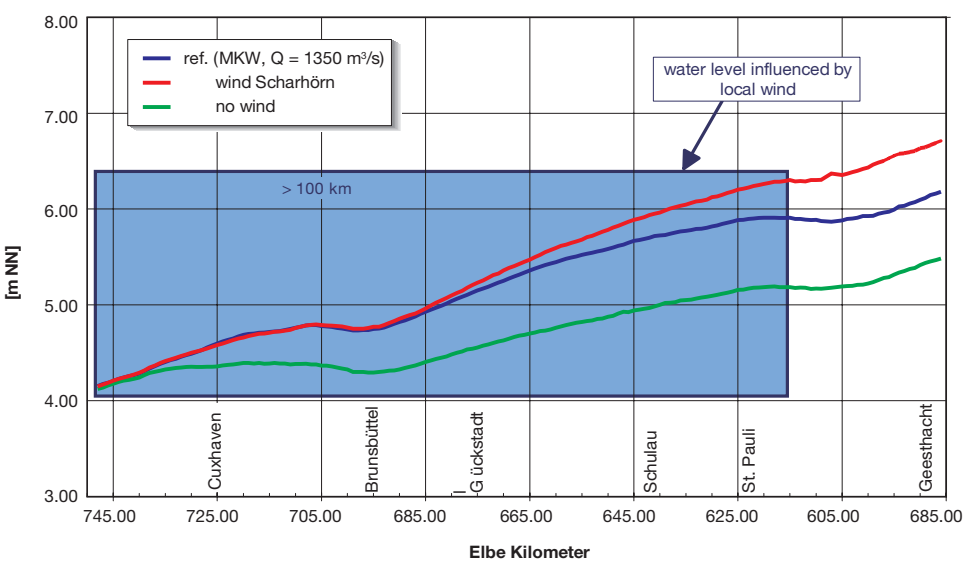

Fig. 6. Change of top surge water level due to wind modification in the Elbe 


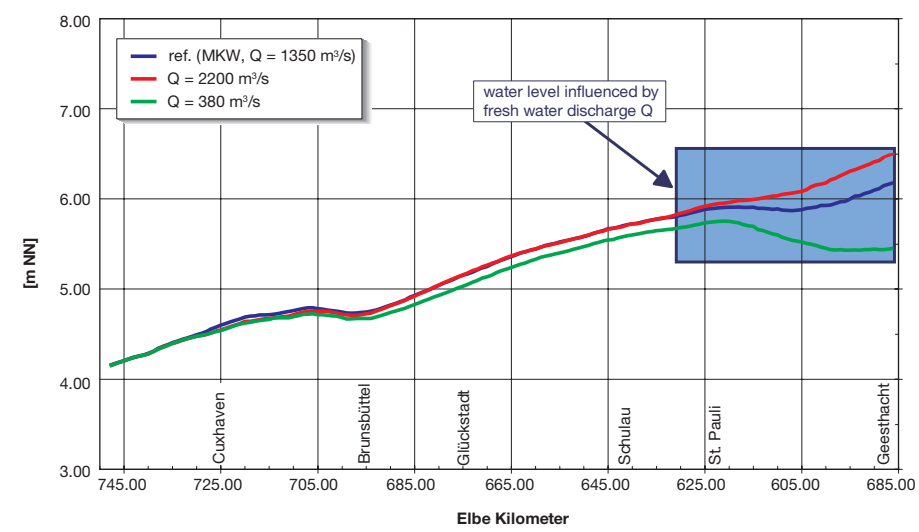

Fig. 7. Change of top storm surge level due to fresh-water discharge in the Elbe

TSWLs. At Hamburg, the differences between the 3 scenarios are more than $100 \mathrm{~cm}$.

The effect of fresh-water discharge on the water levels during the storm surge is shown in Fig. 7. A considerable influence can only be found east of Hamburg, but smaller variations can be observed down the Elbe from Hamburg to the estuary's broadening at Brunsbüttel.

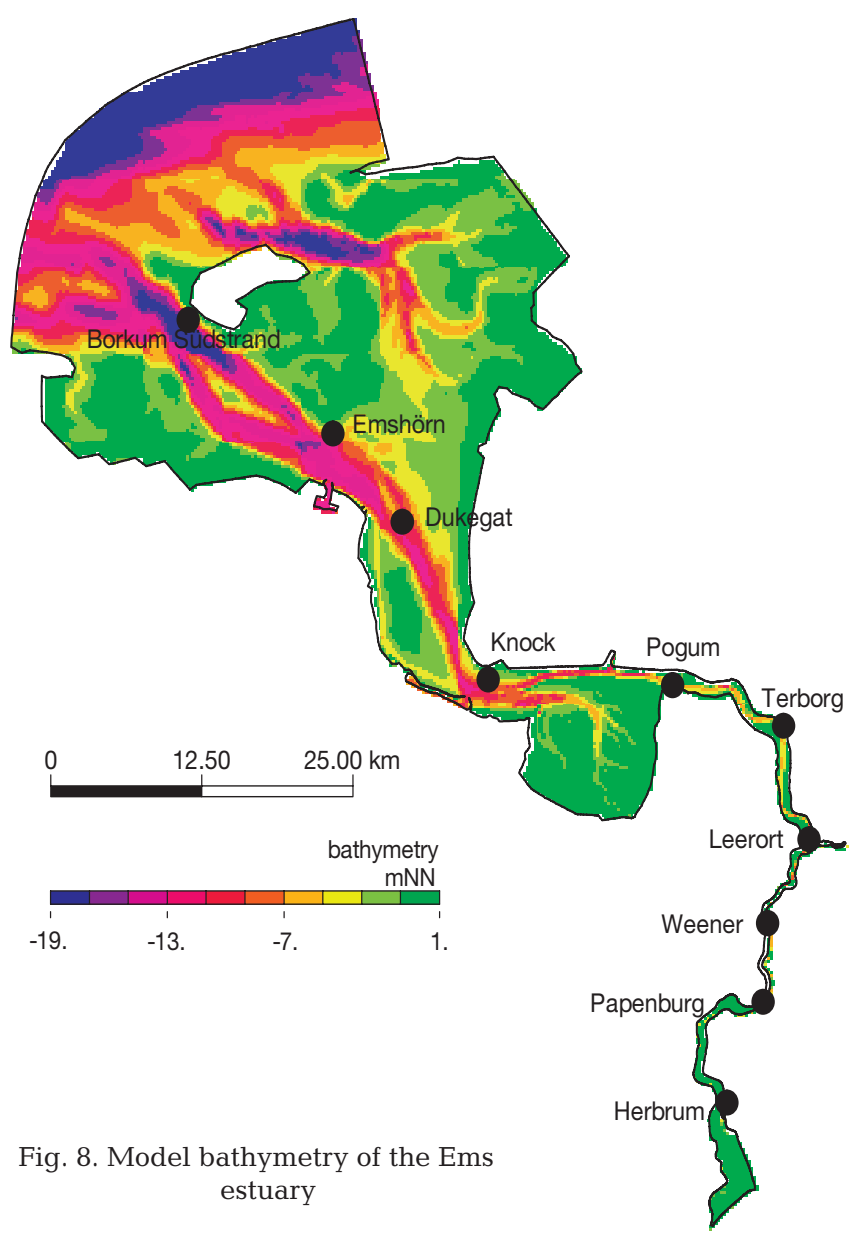

\section{RESULTS FOR THE EMS ESTUARY}

The hydrodynamical model of the Ems was built from 57000 nodes and 110000 triangles; the calculations were made using the TELEMAC-2D hydrodynamical model (Hervouet \& Van Haren 1996). The model domain reaches from an area seaward of the island of Borkum to about $10 \mathrm{~km}$ south of Herbrum. Fig. 8 gives an overview of the complex bathymetry between Borkum and Herbrum which was used for the computations. The divided stream between Dukegat and Knock, the widespread wadden area, the bend at Knock, the Dollart bay southwest of Pogum and the narrow winding river upstream up to Herbrum can be seen clearly.

The distribution of the calculated wind field on January 28, 1994, at noon local time is illustrated in Fig. 9. Wind velocities of 19 to $20 \mathrm{~m} \mathrm{~s}^{-1}$ extend to the Dollart (bay south of Emden). They are significant for the wind setup in this region. (Note that wind velocities lower than $16 \mathrm{~m} \mathrm{~s}^{-1}$ are not shown.)

One important parameter influencing the storm surge in the Ems estuary is the duration of high wind velocities for the entire model area. Long durations can be found at the mouth of the estuary and also over the Dollart (Fig. 10).

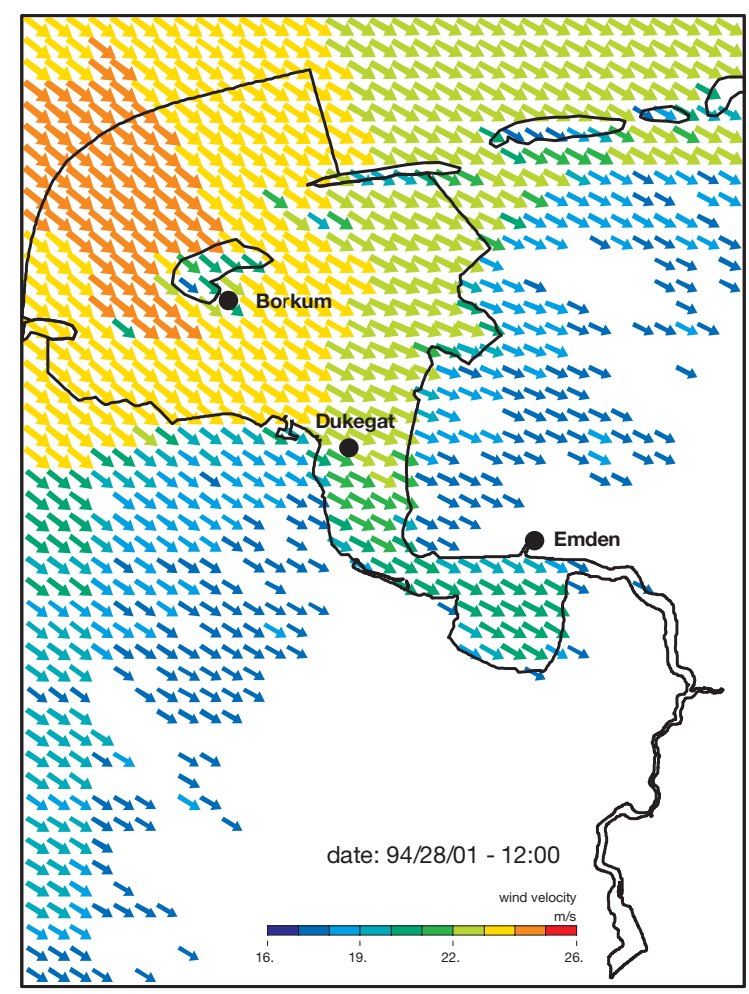

Fig. 9. Wind field vectors over the Ems estuary 


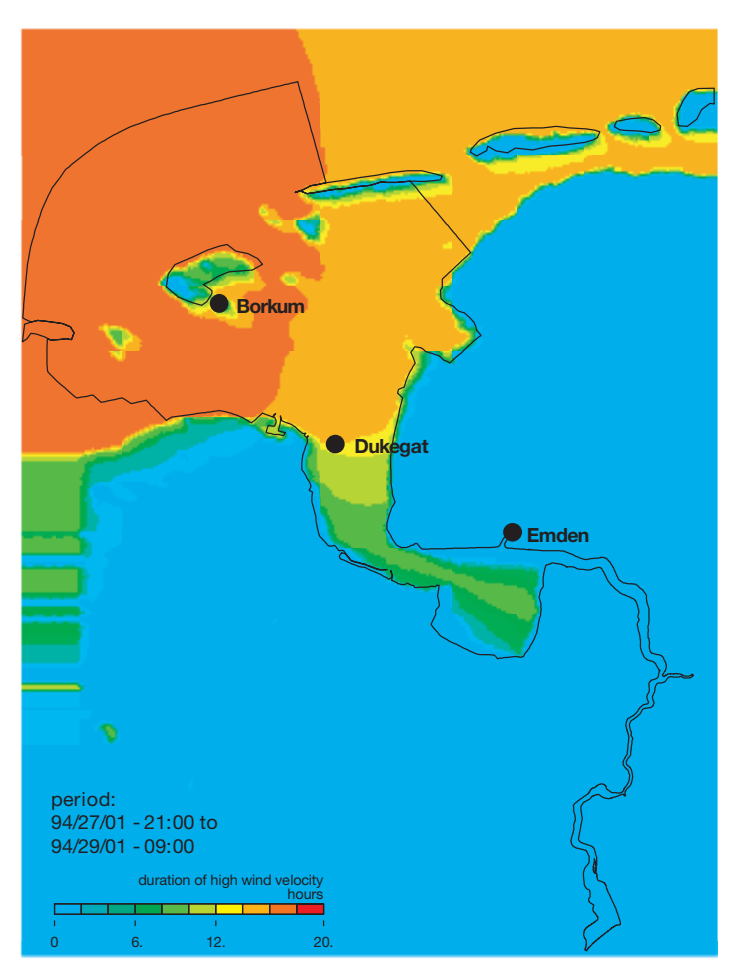

Fig. 10. Duration of maximum wind field over the Ems

The good reproduction of the storm surge dynamics in the Ems estuary is demonstrated by the comparison with tide gauge records. The calculated (blue) and measured (black) water levels for the tide gauge at Leerort are shown in Fig. 11. Further, the impact of the wind inside the domain can be seen by the differences between the green line, indicating the calculation with no wind input over the Ems estuary, and the blue line for the storm surge situation with the MCW wind field.

The influence of regional and local wind field modification on the TSWL diminishes landwards of Emden and the Dollart (see Fig. 12). This corresponds to the extension of the wind field (Figs 9 \& 10).

The influence of various fresh-water discharges is shown in Fig. 13. Alteration of the fresh-water discharge only results in changes of the water level upstream of Leerort when taking into account the maximum discharge of $1200 \mathrm{~m} \mathrm{~s}^{-1}$ (red line).

\section{CONCLUSIONS}

For the German estuaries Ems and Elbe, a high resolution bathymetric numerical storm surge model was developed including all relevant effects for the rise of the water level during storm surge situations. A de-

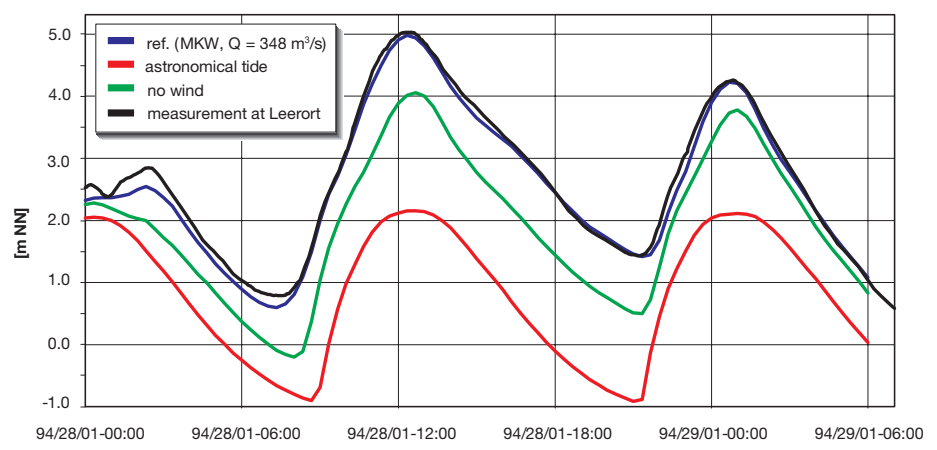

Fig. 11. Measured and calculated water levels at Leerort

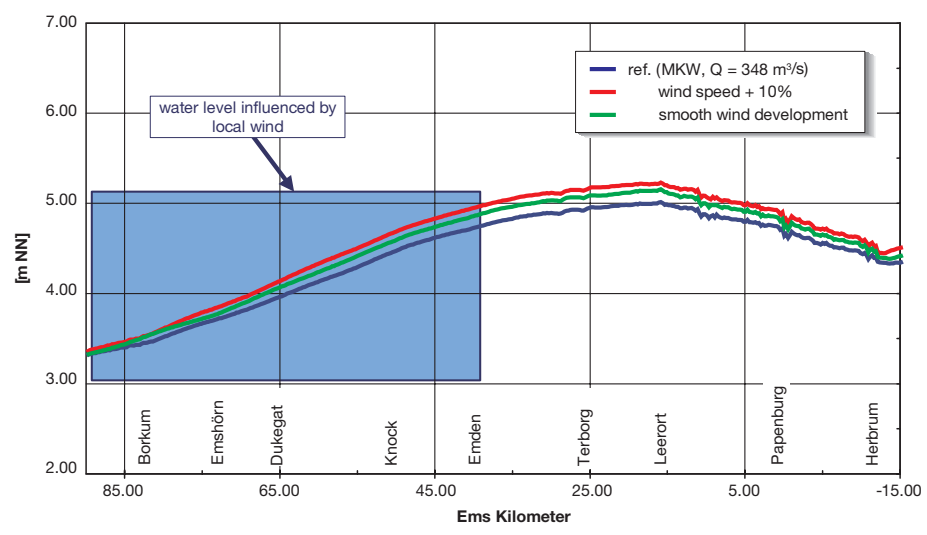

Fig. 12. Change of top surge water level due to wind modification in the Ems

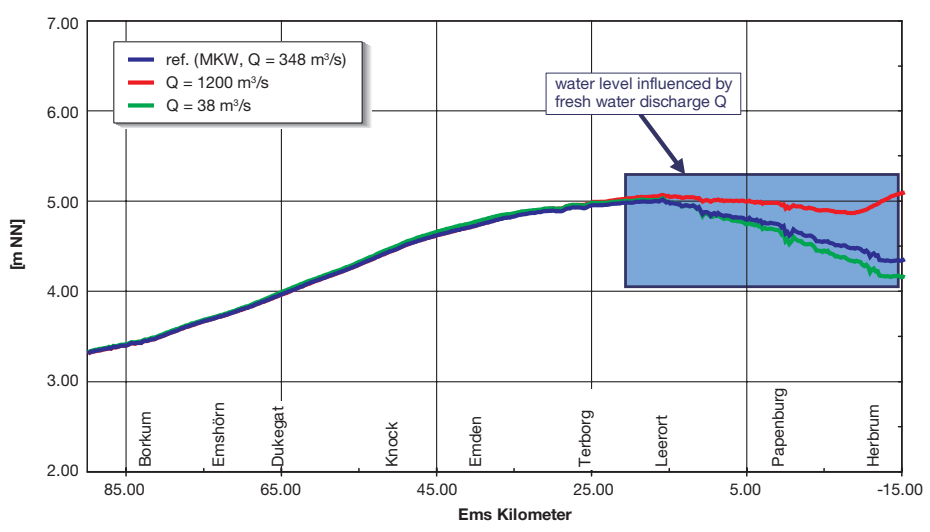

Fig. 13. Change of storm surge level due to fresh-water discharge in the Ems

tailed, sophisticated calculation of regional and local wind fields for the entire domain of each German estuary was carried out using a high horizontal resolution for a significant storm surge.

The models were able to reproduce the storm surge not only for the TSWL but also for the entire rise and fall of the water levels in the entire domain of both investigated estuaries. The impacts of varying freshwater discharge, wind modifications and man-made 
topographical changes were investigated by a coupled meteorological and hydrodynamic model. Using this strategy, the 'sensitivity' of the German estuaries under storm surge conditions was investigated.

For each estuary region it could be determined whether the water level is primarily sensitive to the variations of wind or fresh-water discharge.

Acknowledgements. This study was funded by the Bundesministerium für Bildung und Forschung (BMBF) through the Kuratorium für Forschung im Küsteningenieurwesen (KFKI) Project MTK0600 01/1997-12/1999.

Submitted: December 3, 1999; Accepted: April 3, 2001

\section{LITERATURE CITED}

Casulli V (1990) Semi implicit finite difference methods for two dimensional shallow water equations. J Comput Phys $86: 327-345$

Cheng RT, Casulli V, Gartner JW (1993) Tidal, Residual, Intertidal Mudflat (TRIM) model and its applications to San Francisco Bay, California. Estuar Coast Shelf Sci 36: 363-374

Hervouet JM, Van Haren L (1996) TELEMAC2D Version 3.0 principle note. Rapport EDF HE-4394052B, Electricité de France, Chatou

Schmidt H, Pätsch J (1992) Meteorologische Messungen auf Norderney und Modellrechnungen. Die Küste 54:131-142

Proofs received from author(s): July 5, 2001 